doi: $10.26529 /$ cepsj.39

\title{
Teaching Strategies and the Holistic Acquisition of Knowledge of the Visual Arts
}

EDA BIRSA $^{1}$

$\approx$ Due to the rapid development and advancement within various fields, the scope of knowledge is expanding at a staggering pace. In modern education, experts and teachers makes efforts to eliminate fragmentation of the school curriculum and to modernize the manner of teaching thus optimizing the learning process. In planning art lessons, teachers must adopt an appropriate teaching strategy that enables students to acquire knowledge efficiently and holistically, encouraging the creative solving of art tasks. The present article presents some conclusions of experimental research undertaken to determine the effects of the implementation of a teaching process involving cross-curricular integration. The study involved 274 fifth-grade students and 14 single-class teachers from seven selected Slovenian primary schools. It was found that teachers achieved better learning outcomes by using teaching strategies with cross-curricular integration in sculpting tasks as part of the learning process in art education. The proposed guidelines for teaching art concepts will help teachers to overcome specific obstacles in planning activities for the visual arts learning process, while students will benefit from an increased connection between subjects and integrated knowledge of the visual arts.

Keywords: cross-curricular integration, holistic artistic development, teaching strategies, visual arts

1 University of Primorska, Faculty of Education, Slovenia; eda.birsa@pef.upr.si. 


\section{Strategije poučevanja in celostno pridobivanje likovnega znanja}

EDA BIRSA

$\propto$ Zaradi hitrega razvoja in napredka na različnih področjih se obseg znanja bliskovito veča. Strokovnjaki in učitelji si v sodobnem izobraževanju prizadevajo za odpravo razdrobljenosti šolskega kurikuluma in posodobitev načina poučevanja ter s tem optimizacijo učnega procesa. Učitelji morajo pri načrtovanju učne ure likovne umetnosti izbrati primerno strategijo poučevanja likovnih vsebin, da bo učencem omogočila učinkovito usvajanje in celostno pridobivanje znanja ter spodbudila ustvarjalno reševanje likovnih nalog. V prispevku predstavljamo delne ugotovitve eksperimentalne raziskave, s katero smo želeli ugotoviti učinke izvajanja učnega procesa $\mathrm{z}$ medpredmetnim povezovanjem. V raziskavi je sodelovalo 274 učencev 5. razredov in 14 razrednih učiteljev, ki so poučevali v razredu na izbranih sedmih slovenskih osnovnih šolah. Ugotovili smo, da so z uporabo strategije poučevanja z medpredmetnim povezovanjem pri izvajanju kiparskih nalog v učnem procesu likovne vzgoje učitelji dosegali boljše učne rezultate. Učiteljem bodo usmeritve v načinu poučevanja likovnih pojmov odpravile nekatere ovire pri načrtovanju likovnih aktivnosti $\mathrm{v}$ učnem procesu likovne umetnosti, učencem pa zagotovile večjo povezanost in pridobivanje celostnega likovnega znanja.

Ključne besede: medpredmetno povezovanje, celostni umetnostni razvoj, strategije poučevanja, vizualna umetnost 


\section{Introduction}

The development of new forms of knowledge based on new technological and scientific discoveries has given rise to a large number of academic subjects with very fragmented content. More recently, however, education experts have endeavoured to reintegrate individual, highly specialised disciplines or subject areas. The didactic principle of rationality and economy requires the linking of similar or even overlapping content of different academic subjects. Among the goals of contemporary teaching, efforts to reduce the overburdening of students in acquiring fragmented, over-extensive, and opaque learning content can be identified (Strmčnik, 2001). The correlation between learning and teaching is essential for the individual's cognitive, emotional and psychomotor progress. In the contemporary school, teachers are expected to teach students so as to prepare them for life. They are encouraged to help students to develop critical thinking skills, foresight, and the ability to effectively search and acquire quality information, and hence knowledge (Illeris, 2005; Jarvis, 2005; Stojaković, 1990). To develop effective and sustainable knowledge 'that can be applied when thinking about a variety of problems, we need a wellorganised stock of knowledge acquired in appropriate contexts and with appropriate support, generalised to the abstract level and organised around key concepts' (Rutar Ilc, 2011, p. 97).

When planning art lessons, the teacher must carefully consider devising a strategy that will encourage the students to efficiently acquire, connect, and upgrade their knowledge, as well as to adopt a creative approach to solving art tasks. The traditional concept of teaching and the passive role of the student in the learning process do not meet the challenges of contemporary times. Teaching and learning strategies that have developed and have largely replaced traditional methods are characterised by promoting the active role of students, taking into account their interests and needs, as well as their individual differences in experience, perception, participation and ability to learn various skills (Kobal, 2016; Rutar Ilc, 2011; Strmčnik, 2001; Zhang \& Sternberg, 2005). Contemporary teaching strategies of art content and concepts promote the elimination of certain barriers in managing activities in the art learning process itself, providing better integration of the acquired information about art. The present article lists several art teaching strategies that promote the motivation and creativity of students in artistic expression and encourage the holistic development of artistic abilities. The focus is on a teaching strategy that involves a specific way of teaching and learning, i.e., learning new art skills through the students' own experience, by transferring knowledge and skills to the integration of 
concepts from another subject or from various other subjects. Integration can take place within or across areas of art. The teacher can achieve even more efficient results by integrating art content or concepts and concepts from various subject areas. A well-considered strategy of cross-curricular teaching will motivate students for artistic activity and have an impact on their comprehension of art concepts, while improving their ability to identify the specifics of art materials and tools and promoting their creativity in the implementation of various art tasks (Tacol, 1999, 2002, 2003b).

\section{Visual arts teaching strategies}

Choosing the most effective teaching strategy depends on the students and the learning content. The question arises as to how to teach in a way that increases the quality of students' reception, processing, and use of both previously learned and newly acquired information (Magajna, 1995; Rutar Ilc, 2011). In practice, conflicts occur between different teaching strategies due to a lack of familiarity with different types of learning and a failure to consider the differences between them (Rutar Ilc, 2011). Magajna believes that there is a need to make teachers aware of and sensitive towards the fact that not all teaching strategies are equally effective, and that an appropriate choice of teaching strategies can contribute significantly to quality teaching and learning (Magajna, 1995, p. 69). Zhang and Sternberg (2005) argued that some students learn better through conversation and listening, while others learn through visualisation of content or a variety of creative activities in the learning process, which is why, for more than three decades, teaching professionals have devoted a great deal of research to effective teaching strategies. In art classes, a variety of teaching strategies that inspire students' motivation for creative artistic work and a holistic treatment of art content are used. By adopting an appropriate teaching strategy, the teacher can help students to perfect their artistic and creative abilities, while enabling the effective and unique acquisition of various competencies not necessarily tied to formal education, as there are other vital competencies for life beyond education, such as autonomy, flexibility, responsibility, creativity, among others. (Illeris, 2005).

In dealing with art content, the teacher can opt for 'problem-based classes' (Tacol, 2003b, p. 11). Students are at the centre of the learning process, during which they discover new knowledge and skills through seeking, imagining, providing arguments for, verifying and applying given observations, opinions, and the like. This enables the creative solving of art problems in which students 
avoid stereotypical thinking and established artistic solutions (ibid.). Students can arrive at findings about art and other concepts through knowledge transfer based on their experience and their previous knowledge of art concepts, as well as through their skills in handling art materials and tools. This is called 'experiential learning' (ibid., p. 14). The role of experiential learning is to encourage connections between the visual and the lived learning experience. While conveying abstract knowledge about art concepts and other learning content, the teacher constantly engages students' own experience, both their previous lived experience and that of their current participation in the cognitive process. In this way, students' mental activity is enhanced, and it is easier for them to retain the subject matter (De Bono, 1992; Rutar Ilc, 2011). Comprehensive knowledge of art can be achieved by learning and understanding art concepts in combination with cross-curricular integration. Correlating concepts of different subject areas makes sense because it increases academic achievement based on a more comprehensive learning process and a more contemporary organisation of classes, as shown by the findings of previous research (Drake \& Burns, 2004; Fiske, 1999; Paulič, 2002; Sardoč, 2004; Strmčnik, 2001). When planning crosscurricular connections, teachers are, however, faced with some uncertainties, mostly regarding the dilemma of what and how the teacher should be connecting in order to encourage the successful solution of art tasks and to guarantee that the selected strategy motivates students for work, allowing them to engage in creative artistic expression while also resulting in a holistic understanding of the presented art content (Tacol, 2003b). The teacher should design teaching and learning so that students can experience reality as a whole and not broken down into a variety of disciplines. It is well known that the human brain does not process sensations sequentially but simultaneously, sorting information in complex networks with logically arranged hierarchies of mutual relations $(\mathrm{Ru}-$ tar IIc \& Škerjanc Pavlic, 2010). In the planning of the curriculum, dilemmas often arise regarding the educational goals foreseen by school legislation. In contemporary curricula and the syllabi of individual academic subjects, there is an emphasis on vertical and horizontal linkages and the logical sequence of learning content within a specific subject and between related subject areas (Strmčnik, 2001).

\section{Cross-curricular integration strategies in the visual arts learning process}

Irrespective of the concept or the integration strategy, the subjects included assume different roles, i.e., an emphasised, lead, or supporting role 
(Rutar IIc \& Pavlič Škerjanc, 2010). Depending on their complexity and intensity, connections within cross-curricular integration can be classified into various types: the most basic linking, whereby a teacher can make reference to specific subjects in their interdisciplinary correlation but cannot influence the planning and implementation of these subjects, and the more complex correlations represented by integration through common themes or learning content, activities, methods, and procedures, as well as through a joint problem issue. When planning connections, teachers choose an appropriate integration element, which can be represented by an activity, content, tools, forms and methods, a teaching process or method (project approach, active learning), a thought process (development of creative and critical thinking), skills (ability to solve problems), a specific competency (reading and digital capability, learning to learn, etc.) or a concept (interculturalism, human rights, etc.) (ibid., pp. 27-40).

In non-Slovenian literature, experts demonstrate the cross-curricular integration of learning content in the form of models or schemes. These differ according to the different approaches, the number of stages in cross-curricular connections, and the theoretical frameworks. Drake concludes that the individual strategies of integration are equivalent, that there is no better or worse way, but that certain approaches are more appropriate than others, depending on the context in which they are used. The integration of content within a single subject or across subjects is presented by the author as a continuum or a six-speed principle of scalable integration (Drake, 1998). Fogarty describes two models of cross-curricular integration. The ten-level model shows ten different levels of integration. The first three levels (fragmented, connected and nested) are characterised by connections taking place within the single subject, while the threaded, shared, webbed, sequenced, and integrated levels involve integrating content across subjects, with connections at the so-called immersed and networked levels being established independently in the students' consciousness (Fogarty, 2009, p. 11). The first dimension of the model of three dimensions or triple dimension, in contrast, is represented by a vertical distribution of curriculum content from the preschool period until the completion of secondary education, whereby the learning content is continuously upgraded and complemented. The second dimension is represented by the breadth and depth of knowledge resulting from the integration of individual subjects, while the third dimension indicates the linking of skills, topics, concepts and content that are common to different subjects and subject areas. This method of integration allows for an increase in the impact of learning in an integrated way so that students can integrate ideas and concepts of different subjects in order to solve problems or problem situations (ibid.). 
When implementing cross-curricular connections, teachers can choose between different forms of cooperation. They can choose to exchange ideas, which involves regularly alternating their roles as bearers, moderators and archivists of data (in paper or electronic form). Discussion is a form of cooperation in which teachers organise systematic, structured, and guided discussions on current topics and proposals, and formulate conclusions. Two of the forms of cooperation directly involve the students: joint learning activities and the exchange of teachers. Rutar IIc and Pavlič Škerjanc (2010) listed some examples of joint activities: teachers can choose to change places with their colleagues in oral examinations, they can organise knowledge challenges, or they can arrange role plays between the different classes in which they include life situations (ibid.).

All these possibilities of cross-curricular connections can also be used in teaching art. Duh (2011) describes cross-curricular integration that involves the integration of art class content from different areas of art. With cross-curricular integration, the more general objectives of art education are implemented in addition to achieving the goals of individual areas of art. The author distinguishes between conceptual integration, the integration of procedural skills and theme integration. Conceptual integration consists of the integration of concepts and content treated simultaneously by the teacher in art classes and in other subjects and used in the implementation of the same art task. The integration of procedural skills is realised when the acquired procedural knowledge of one or more academic subjects contributes to the learning process about the laws of another subject area. Thus, the types of procedural skills acquired in a given subject can serve as a tool for gaining an understanding of art education, and vice versa. Theme integration is aimed at deepening the knowledge of and experiencing the selected content, when verbal descriptions are transferred to the language of visual arts (ibid., p. 96).

When planning the learning process, the teacher must choose appropriate learning content and envisage the interweaving and linking of the objectives and content of the different subjects. The acquisition of knowledge and cognitive strategies must be established by the teacher through the equitable treatment of the concepts and procedural objectives of different subject areas, including the promotion of the creative solving of art tasks. Attention must also be paid to the choice of teaching aids, approaches to content or concept integration, and strategies for planning the individual learning steps. In the choice of approaches to work, the teacher must take into account the artistic abilities, personality traits, needs, and aspirations of the students, and should not impose his or her own views on the highlighted problem task. The teacher promotes the active role of all students in perception, experience, exploration, and integration of personal experience, as well as in establishing connections between and acquiring the art 
concepts and other concepts in question, on the basis of which students discover their own strategies for problem solving (Tomšič Čerkez, 2009).

The teacher and the students can become familiar with new concepts in art and related fields through completing assignments in verbal or visual problem solving. The departure point for the shaping of a problem task can be devised by the teacher in different ways but has no bearing on the assertion that cross-curricular integration must be implemented through concepts (Tacol, $2002,2003 \mathrm{~b})$. In planning the learning process, the teacher should carefully select the appropriate methods of and approaches to work, drawing on a number of the aforementioned models of integration by Slovenian and foreign experts.

\section{Integrating art concepts with other concepts and plan- ning sculpting tasks}

The learning process in art classes is repeatedly marked by uncertainties regarding the planning and implementation of cross-curricular connections. For example, when dealing with certain learning content within a subject, teachers include artistic expression without specific artistic goals. Art in the learning process thus only serves to enrich the process of learning or revising the subject matter, and the artworks realised by students in this setting cannot be treated the same as those created in art classes. In practice, this kind of integration method is often seen as an appropriate way of establishing cross-curricular connections between art education and other curriculum areas. The problematic aspect of such integration is the artistic expression, which encourages neither artistic thinking nor an independent search for original and spontaneous art solutions. The resulting artwork is often carried out mechanically and schematically; all too often, it is limited to copying (Duh \& Vrlič, 2003; Rutar Ilc, 2011; Tacol 2002, 2003a, 2003b). For the effective integration of art concepts with other academic concepts, the teacher must carefully prepare for lessons and reflect on and anticipate what students can be expected to achieve by following such a strategy. The teacher must consider the procedural and the art objectives of individual art tasks carefully and consistently. The integration of concepts can take place within or across subjects sharing specific content, while cross-disciplinary links can be purely instrumental in learning about the specifics of art materials and procedures or in achieving an understanding of art concepts. The teacher can implement integration based on the learner's experience, which means that the learner applies concepts previously acquired in other subjects to become familiar new art concepts, or, conversely, notions previously acquired in art classes can be used as a starting point for learning about concepts in other academic subjects (Tacol, 2003b). 


\section{Method}

In an effort to improve the quality of the learning process in the arts and to achieve the efficient acquisition of a holistic knowledge of the visual arts, we have carried out an experimental study.

The object of the experimental research was to determine the impact of the implementation of art classes with cross-curricular integration on pupils, specifically on:

- $\quad$ greater creativity of pupils in solving artistic tasks;

- $\quad$ student's successful understanding of visual arts;

- $\quad$ successful motivation of pupils to solve artistic tasks.

This paper presents some of the research carried out to determine the effects of the implementation of art classes with cross-curricular integration. We were concerned about the impact of cross-curricular connections on students' understanding of art concepts and their motivation and creativity in solving sculpting tasks.

According to the definition of the problem we have formed the following general (Hs) and specific ( $\mathrm{Ha}, \mathrm{Hb}, \mathrm{Hc}, \mathrm{Hd})$ hypothesis:

Hs: With cross-curricular integration in the implementation of art tasks in art education teachers would achieve better learning outcomes for students by adopting teaching strategies than in classes with no crosscurricular integration.

Ha: The cross-curricular integration of art concepts and concepts from other academic subjects encourages greater creativity of students in solving art tasks.

$\mathrm{Hb}$ : The cross-curricular integration of art concepts and concepts from other academic subjects influences students' comprehension of art concepts.

Hc: The cross-curricular integration of art concepts and concepts from other academic subjects impacts students' motivation to solve art tasks.

Hd: The cross-curricular integration of art concepts and concepts from other academic subjects enhances the incorporation of knowledge about the specifics of art materials, as well as tools for artistic expression.

The study was conducted in one school year (2011/2012) in regular art classes following the established arts curriculum. A total of 274 fifth-grade students participated in the study, along with 14 teachers from seven selected Slovenian primary schools, both urban and rural. Two classes were selected at each primary school. The experimental group comprised 160 pupils and 8 teachers, 
while the control group was populated by 114 students and 6 teachers. All the schools had the same material conditions for the implementation of art classes.

The experimental study was composed of several parts. To verify the initial state, we checked the results of student performance from the previous year, using data such as the final marks in all the fourth-grade subjects of the students involved in the research. The teachers and students then performed a sculpting task without any specific instructions. After establishing the initial state, the experiment was carried out. The experimental factor had two modalities:

1. The traditional way of teaching and learning;

2. Implementation of the learning process through the acquisition of art concepts using cross-curricular integration.

In the context of the experimental study, the students from the control and experimental groups implemented four sculpting tasks as part of the regular art curriculum. The art tasks were realised by the teachers in the same period. The teachers who taught in the control group gave lessons on the basis of the established methods of teaching. The lesson plans for the implementation of the art tasks in the control group were prepared by the teachers themselves, without additional instructions, on the basis of allocated tasks. The remaining details necessary for the implementation of the art tasks were defined by the teachers based on their discretion.

The teachers who taught in the experimental group were provided with detailed instructions on how to carry out their art lessons (except for the execution of the sculpting tasks in the initial state). The realisation of individual sculpting tasks with cross-curricular integration required the inclusion of various subjects, with the number of subjects and the subject areas being determined according to the (art) concepts that the students had been previously familiarised within art lessons. The concepts chosen for cross-curricular integration were selected on the basis of the existing curricula for Art, Science and Technology, Mathematics, Social Studies, and Physical Education. The selection of integrative concepts varied depending on the art task. Most of the selected concepts were taken from the curricula for the fifth grade of the nine-year primary school programme. In the second sculpting task, for the purposes of cross-curricular integration, we chose a concept from the curriculum for Science and Technology, which the students had learnt about in the fourth grade. In this case, a vertical cross-curricular connection was established, while the other sculpting tasks were dominated by horizontal cross-curricular connections between the concepts of different fifth-grade subjects.

In the first sculpting task, the students were guided towards learning 
about the specificities of the art concepts of form and materials. The starting point for cross-curricular integration was found by the teacher in the concepts of mathematical shapes and bodies, while the concept of materials (waste, natural, artificial) was taken from Science and Technology. In the second sculpting task, the teacher linked the concept of linear surface treatment to the concepts of the diversities of surfaces and material properties from Science and Technology. In the third sculpting task, the students learnt the concepts 'dynamic' and 'static', as well as the surface treatment of the sculpture with paint, whereby they had to be alert to the stability or balance of the sculpture. The students were asked to recall the knowledge of balance that they had previously acquired in a drawing task, connecting it with the concept of balance in Physical Education. They were also asked to recall the concept of stability in the construction of buildings, which they had mastered in Social Studies, and the concept of balance in nature, studied in Science and Technology. In the fourth and last sculpting task, the students learnt about the visual concept of relief. The point of departure for the adoption of this concept was located in the related topic of relief in Social Studies and in various topics within Science and Technology.

In executing the connections, which were based on the teaching of a single teacher, the subject Art had the 'lead' role (Rutar IIc \& Pavlič Škerjanc, 2010). Given the degree of complexity and the integration method, cross-curricular connections were established through linking, in which the nested category of integration (according to Fogarty, 2009) was used as a strategy, meaning that the concepts previously acquired in another subject or subject area were used to assist in learning or revisiting the particularities of certain art concepts. By means of the selected concept or multiple concepts, the teachers systematically emphasised the cross-curricular correlation with one or more subjects, but without exerting an influence on the design or implementation of the subject in question. Due to the overall scope of the study, we were limited to cross-curricular integration in the context of art concept acquisition. In the acquisition of manual skills and the cultivation of an aesthetic sense for the representation of students' own art products, we also relied on prior experience.

Survey instruments were designed for the purpose of data collection. Each student was assigned a unique code, which s/he retained throughout the research and in data collection. Both in the initial stage and following the experimental part of the study, the students took a written test to verify their understanding of art concepts. Both tests were verified for construct validity with factor analysis methods, and for reliability with the Cronbach alpha coefficient with factor analysis. Objectivity was measured by calculating the difficulty coefficient of the individual tasks, which was found to be within the 
appropriate range in both cases. The discriminant coefficient was also calculated, and the tasks were found to be duly discriminatory. During the lessons, the teachers of the two groups observed the students and evaluated the effects of the implementation of the learning process. Data for the analysis of motivation was collected based on observation and on the teachers' evaluation of the students' responses to the chosen teaching strategy, facilitated by observation sheets. The level of the students' motivation was verified at the beginning, middle and conclusion of the art class. Throughout the lesson, the teacher observed whether the students were highly motivated, very motivated, motivated, poorly motivated, or not motivated. Using a scale and the criteria for the identification of creativity, the students' level of creativity was assessed during the learning process while dealing with the sculpting tasks, by assigning a grade from 1 to 5 . The resulting sculptural works were evaluated by three independent teachers. To this end, a computer programme was developed to facilitate and increase the efficiency of the evaluation of works (accelerated assessment, less paperwork, better organisation, fewer human errors).

The data were analysed with SPSS software. Descriptive statistics were used to present the results of the individual elements of artistic creation/engagement observed in the context of the experimental group and the control group. To determine the differences between the experimental and control group prior to the experiment, inferential statistics were used in addition to descriptive statistics; specifically, a multivariate discriminant analysis was employed to examine both variations in the initial state and differences in performance between the control group and the experimental group. Fisher discriminant analysis was selected for discriminant analysis, as, unlike most other methods, it does not presuppose multivariate normal distribution.

\section{Results}

In the course of the experiment, both student groups were observed/ assessed for the following elements: motivation, creativity in solving the four sculpting tasks, and art concept comprehension (written examination, art products). A comparison of the grading of the observed elements between the control group and the experimental group is shown in Table 1. The comparison of the average grading for all elements observed between the two student groups was conducted with discriminant analysis. 
Table 1

Comparison of the post-experiment state based on the grades for the selected elements/criteria for the experimental group and the control group

\begin{tabular}{|c|c|c|c|c|c|}
\hline State & Assessment element & $\begin{array}{c}\text { Lowest } \\
\text { grade }\end{array}$ & $\begin{array}{l}\text { Highest } \\
\text { grade }\end{array}$ & $\begin{array}{c}\text { Average } \\
\text { grade }\end{array}$ & $\begin{array}{l}\text { Standard } \\
\text { deviation }\end{array}$ \\
\hline \multirow{5}{*}{ 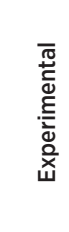 } & Motivation & & & & \\
\hline & Sculpting task & 2.22 & 5.00 & 3.78 & .64 \\
\hline & Creativity & & & & \\
\hline & Sculpting task & 2.13 & 4.90 & 3.96 & .51 \\
\hline & Art concept comprehension & .35 & 2.05 & 1.42 & .31 \\
\hline \multirow{5}{*}{$\begin{array}{l}\overline{0} \\
\text { 응 } \\
\text { o }\end{array}$} & Motivation & & & & \\
\hline & Sculpting task & 2.22 & 5.00 & 3.49 & .76 \\
\hline & Creativity & & & & \\
\hline & Sculpting task & 1.77 & 4.57 & 3.10 & .61 \\
\hline & Art concept comprehension & .40 & 1.95 & 1.26 & .33 \\
\hline
\end{tabular}

Table 2

Comparison of the effects of the experiment on students between the experimental group and the control group

\begin{tabular}{ccccc}
\hline Discriminant function & Wilks' lambda & $\chi^{2}$ & Degrees of freedom & Degree of importance \\
\hline 1 & .499 & 162.250 & 3 & .000 \\
\hline
\end{tabular}

The results of the discriminant analysis (Table 2) show that the difference between the results of the experimental group and control group (from the point of view of observing the aforementioned three elements) is statistically significant $(\mathrm{P}=. \mathrm{ooo})$. Based on the assessment of Wilks' lambda (Table 2), it can be concluded that 49.9 per cent of the tested variables (three elements of observation) fail to contribute to the clarification of the differences in the effects of the experiment between the two groups of students.

Table 3

The canonical correlation coefficient

\begin{tabular}{ccccc}
\hline $\begin{array}{c}\text { Discriminant } \\
\text { function }\end{array}$ & $\begin{array}{c}\text { Own canonical } \\
\text { variate }\end{array}$ & $\begin{array}{c}\text { Percentage (\%) of } \\
\text { explained variance }\end{array}$ & $\begin{array}{c}\text { Cumulative percentage } \\
\text { (\%) of explained variance }\end{array}$ & $\begin{array}{c}\text { Canonical correlation } \\
\text { coefficient }\end{array}$ \\
\hline 1 & .953 & 100 & 100 & .712 \\
\hline
\end{tabular}


Based on the assessment of the canonical correlation coefficient (.712), as shown in Table 3, it is evident that the differences between the two groups of students are great/strong.

Table 4

Structure coefficients of the discriminant function of the student groups

\begin{tabular}{lccc}
\hline $\begin{array}{l}\text { Variable (observed element of } \\
\text { the experiment) }\end{array}$ & Correlation coefficient & t-statistics & Degree of importance \\
\hline Creativity & .753 & 17.01 & .000 \\
Art concept comprehension & .324 & 5.09 & .000 \\
Motivation & .255 & 3.92 & .000 \\
\hline
\end{tabular}

The correlation coefficients of the variables (Table 4) range from .753 (creativity) to .255 (motivation). The greatest difference in the effects of the experiment between the experimental group and control group was in the assessment of creativity. The experiment showed that the experimental group made more progress than the control group in creative engagement in the implementation of the sculpting tasks, as reflected in the grades achieved by students in sculptural works. It was assumed that 'the cross-curricular integration of art concepts and concepts from other academic subjects encourages the greater creativity of students in solving art tasks'. The results obtained show that, based on their grading, the students in the experimental group displayed better performance and more creativity in executing the sculpting tasks, thus enabling us to confirm the specific hypothesis (Ha).

The majority of students showed the capability of creative thinking, which was reflected in their artistic expressions. Many works indicate interesting individual approaches to solving sculpture assignments (see Figures 2 and 4). The art work by a student from the experimental group shows an interesting and imaginative theme in the sculpting of a statute (see Figure 2). He understood the peculiarities typical of sculpture works made of various statuary materials and perceived their expressive possibility. When making a sculpture, a student from the control group failed to give sufficient consideration of the properties of art materials (i.e., waste materials, paper, etc.). Art theme, materials and aids presented did not encourage the student to design unusual forms (see Figure 1). 


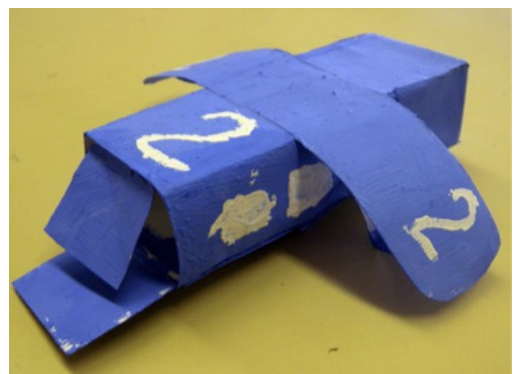

Figure 1. Art work by a control group student 105BK.

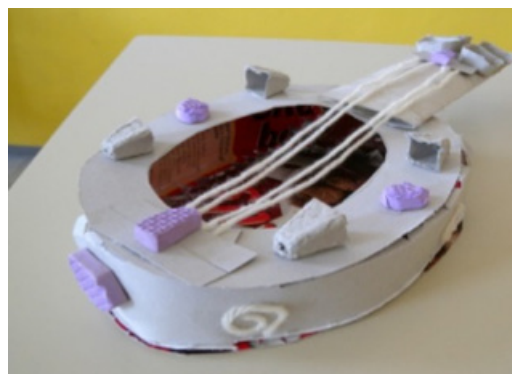

Figure 2. Art work by an experimental group student 165BE.

In conclusion, we can confirm the specific hypothesis $(\mathrm{Hb})$ predicting that 'the cross-curricular integration of art concepts and concepts from other academic subjects influences students' comprehension of art concepts'. The good performance of the students in the experimental group is demonstrated by the results of the written test and the sculptural works created.

In addition to the assessment of the works produced in the context of the individual sculpting tasks, we also obtained information on the responses of the students exposed to the suggested teaching strategy during the implementation of the learning process. An analysis of student motivation shows that the students of the experimental group were more motivated than their peers in the control group. Therefore, the specific hypothesis $(\mathrm{Hc}$,$) positing that 'the$ cross-curricular integration of art concepts and concepts from other academic subjects impacts students' motivation to solve art tasks' can be confirmed.

Based on the grading of the sculptural works produced, we can also confirm the specific hypothesis (Hd), which assumes that the implementation of the learning process through the use of cross-curricular connections between art concepts and concepts from other academic subjects enhances the incorporation of knowledge about the specifics of art materials, as well as tools for artistic expression.

When designing sculptures, students from the experimental group displayed more enthusiasm for the consideration of theoretical premises. The sculpture in Figure 4 shows thoughtfully incorporated cognitions about relief as an artistic concept. The student used two-dimensional material and created interesting projections on the surface thus creating a low relief. Sculpture works made by the control group students suggest that much consideration was given to the content of the theme offered. Students did not quite grasp the difference between a sculpture work and relief, which can also be seen in a control group student's sculpture work (see Figure 3). The art work shows no trace of creativity in using the materials, resulting in a design with a simple relief. 


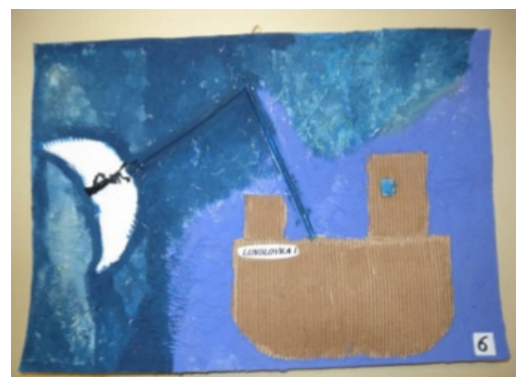

Figure 3. Art work by a control group student $65 \mathrm{BK}$.

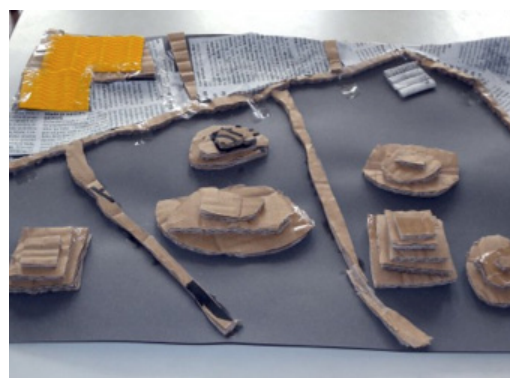

Figure 4. Art work by an experimental group student $25 \mathrm{AE}$.

\section{Conclusion}

The experimental study aimed to show the effects of the implementation of a learning process with cross-curricular integration. Based on the results obtained in the study, we can confirm the general hypothesis (Hs), in which we foresaw that teachers would achieve better learning outcomes for students by adopting teaching strategies with cross-curricular integration in the implementation of art tasks in art education than in classes with no cross-curricular integration.

Among the teachers who taught in the control group, we observed more inconsistencies and misunderstandings regarding the content, and a lack of clarity in preparation for the learning process of art classes, as well as a poor understanding of the planning of art tasks (especially in the field of sculpture). During lesson preparation, we repeatedly witnessed the teachers' lack of familiarity with art terms, which resulted in the poor realisation of the tasks by the art students. We also noticed the teachers' clumsiness in the use of teaching aids and tools, such as the use of inappropriate images. In some cases, the teachers did not use illustrative materials at all, thus failing to deepen the students' understanding of art concepts. In preparing their lessons, the teachers did, in fact, plan the integration of art content with other subjects, as evidenced in the heads of the lesson preparation sheets, but they failed to implement it in the actual classes. In some cases, there was evidence of attempts to implement cross-curricular connections, but they were poorly executed. These attempts were predominantly focused on the common practice of the depiction of artistic motifs, i.e., exploiting art lessons to achieve the objectives of other subjects (Tacol, 2003a, 2003b). In some cases, the teacher clearly influenced the artistic expression as well as the creativity of the students, resulting in the group producing exactly the same art products (see Figures 5 and 6). By giving 
extremely precise instructions on the sculpting procedure (e.g., from wire or DAS modelling clay), the teachers influenced the final appearance of the art products (sculptures), whereby the focus was on the pleasing appearance of the sculptures rather than on the incorporation of the acquired art concepts.

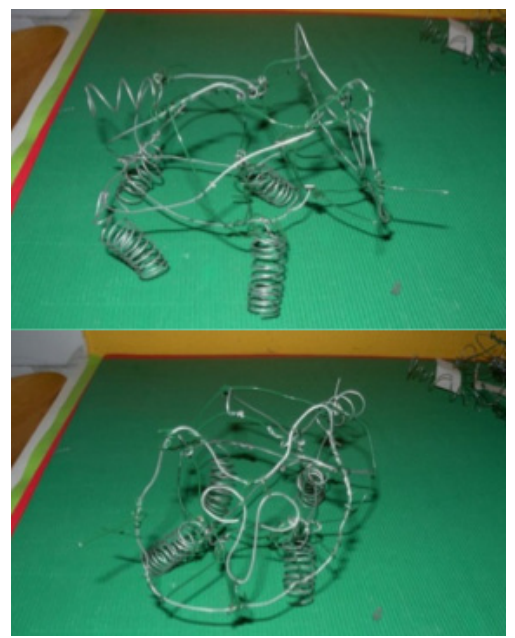

Figure 5. Art work by a control group student 95AK.

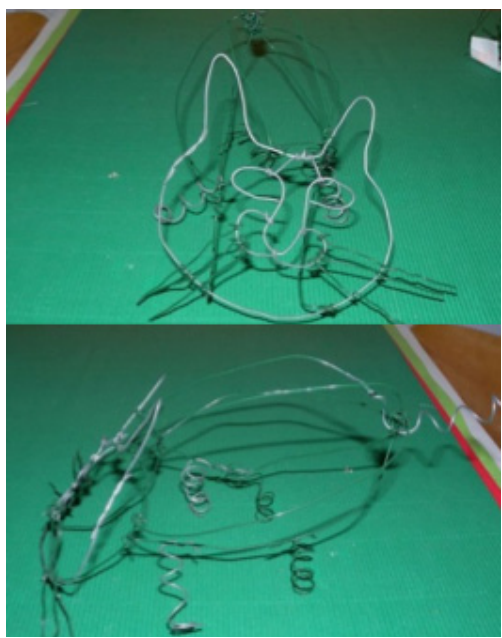

Figure 6. Art work by a control group student $35 \mathrm{AK}$.

The results of the experimental study demonstrate the effectiveness of the applied teaching strategy using the nested category (Fogarty, 2009) of concept-based cross-curricular integration, with the teachers of the experimental groups achieving better learning outcomes in the implementation of the learning process than their colleagues who implemented art classes following the usual (traditional) model did. The students in the experimental group were more successful in solving written tests and creating art products, showing greater progress in the comprehension of art concepts.

It was found that the active participation of students in the implementation of the learning process with cross-curricular integration affects motivation and creativity in the implementation of art tasks, as well as having a long-term impact on the retention of art content and art concepts, and on the understanding of art issues in the context of everyday life. Furthermore, the results obtained demonstrate the greater motivation and creativity of the students in the experimental group in performing their sculpting tasks, which provides further evidence of the positive effects of the use of cross-curricular connections in art education.

Guidelines on how to achieve creativity, motivation and the successful acquisition and retention of art concepts will assist teachers who seek a better 
implementation of cross-curricular integration in teaching art. In the long run, such guidelines will also lay the foundations for students' lifelong learning. We have compiled guidelines (prepared lesson plans) that direct teachers in the implementation of cross-curricular connections in art classes on the conceptual level. In so doing, we have sought to encourage more efficient and holistic teaching methods. Single-class teachers will thus be assisted in developing their own effective teaching strategies. In the present study, we offer examples of some of the less complex forms of cross-curricular integration. The selected option involving the nested category (Fogarty, 2009) is a good starting point for more complex ways of implementing cross-curricular connections that require teamwork of two or more teachers, the implementation of the learning process in different time periods, etc. Such approaches could be the topic of further research. A carefully selected strategy of cross-curricular integration in the learning process of art classes will certainly contribute to the successful acquisition of sustainable and integrated artistic skills.

\section{References}

Bransford, J. D., Brown, A. L., \& Cocking, R. R. (200o). How people learn: Brain, mind, experience, and school. Washington, D.C.: National Academy Press.

De Bono, E. (1992). Tečaj mišljenja [Thinking course]. Ljubljana: Ganeš.

Drake, S. M. (1998). Creating integrated curriculum. Proven ways to increase student learning. Thousand Oaks, CA: Corwin Press.

Drake, S. M., \& Burns, R. C. (2004). Meeting standards trough integrated curriculum. Alexandria, VA: Association for Supervision and Curriculum Development.

Duh, M., \& Vrlič, T. (2003). Likovna vzgoja v prvi triadi devetletne osnovne šole. Priročnik za učitelje razrednega pouka [Art education in the first cycle of nine-year primary school. A handbook for singleclass teachers]. Ljubljana: Rokus.

Duh, M. (2011). Likovna vzgoja [Art education]. In L. Marjanovič Umek [et al.] (Eds.), Lili in Bine. Priročnik za poučevanje in medpredmetno povezovanje v prvem triletju (pp. 38-98). Ljubljana: Rokus Klett. Fiske, E. B. (1999). Champions of change. The impact of the arts on learning. Retrieved from http:// artsedge.kennedy-center.org/champions/pdfs/ChampsReport.pdf

Fogarty, R. (2009). How to integrate the curricula? (3rd ed.). Thousand Oaks, CA: Corwin A SAGE Company.

Illeris, K. (2005). A comprehensive understanding of human learning. In P. Jarvis \& S. Parker (Eds.), Human learning: An holistic approach (pp. 87-100). London, UK, \& New York, NY: Routledge. Jarvis, P. (2005). Towards a philosophy of human learning: An existentialist perspective. In P. Jarvis \& S. Parker (Eds.), Human learning: An holistic approach (pp. 1-15). London, UK, \& New York, NY: Routledge. Kobal, L. (2016). Likovna ustvarjalnost: mnenja učiteljev likovne umetnosti v slovenskih nižjih srednjih 
šolah v Italiji in italijanskih osnovnih šolah v Sloveniji [Artistic creativity: The views of teachers of fine arts in the Slovenian lower secondary schools in Italy and the Italian elementary schools in Slovenia]. Annales, Series Historia et Sociologia, 26(2), 343-354.

Magajna, L. (1995). Aplikacija spoznanj na procese učenja in poučevanja [Application of understanding on process of learning and teaching]. In B. Marentič-Požarnik, L. Magajna, \& C. Peklaj (Eds.), Izzivi raznolikosti. Stili spoznavanja, učenja, mišljenja (pp. 69-74). Nova Gorica: Educa.

Paulič, O. (2002). Medpredmetno povezovanje v gimnazijah [Cross-curricular integration in grammar schools]. Vzgoja in izobraževanje, 33(1), 67-70.

Rutar Ilc, Z., \& Pavlč Škerjanc, K. (2010). Medpredmetne in kurikularne povezave: priročnik za učitelje [Cross-curricular and curricular integration: A teachers' handbook]. Ljubljana: Zavod Republike Slovenije za šolstvo.

Rutar Ilc, Z. (2011). Poučevanje za razumevanje [Teaching for understanding]. Sodobna pedagogika, 62(1), 76-99.

Sardoč, M. (2004). Medpredmetno povezovanje vzgojno-izobraževalnega procesa v 9-letni osnovni šoli: evalvacijska študija. Zaključno poročilo [Cross-curricular integration in the education process of nineyear primary school: An evaluation study. Final report]. Ljubljana: Pedagoški inštitut.

Stojaković, P. (1990). Psihološki uslovi transfera učenja. Transfer znanja i reforma obrazovanja [Psychological conditions for the transfer of learning. Transfer of knowledge and the education reform]. Beograd, Sarajevo: Svjetlost, Zavod za udžbenike i nastavna sredstva.

Strmčnik, F. (2001). Didaktika. Osrednje teoretične teme [Didactics. Central theoretical topics]. Ljubljana: Znanstveni inštitut Filozofske fakultete.

Tacol, T. (1999). Didaktični pristop k načrtovanju likovnih nalog. Izbrana poglavja iz likovne didaktike [A didactic approach to the design of art tasks. Selected topics from the didactics of the visual arts]. Ljubljana: Debora.

Tacol, T. (2002). Problemski pouk likovne vzgoje in medpredmetno povezovanje v novem kurikulumu [Problem-based learning in art education and cross-disciplinary connections in the new curriculum]. Sodobna pedagogika, 58(2), 40-49.

Tacol, T. (2003a). Likovna vzgoja in medpredmetno (interdisciplinarno) povezovanje [Art education and cross-curricular (cross-disciplinary) integration]. Likovna vzgoja, 5(23-24), 27-30.

Tacol, T. (2003b). Likovno izražanje. Didaktična izhodišča za problemski pouk likovne vzgoje $v$ devetletni osnovni šoli [Artistic expression. Didactic starting points for problem-based learning in the art education of nine-year primary school]. Ljubljana: Debora.

Tomšič Čerkez, B. (2009). Medpredmetno povezovanje in individualizacija kot motivacijsko sredstvo za likovno izražanje [Cross-curricular integration and individualization as a motivation mean for artistic expression]. In M. Prevodnik (Ed.), Motivacija za inovativnost in ustvarjalnost mladih: 2. mednarodni kolokvij. Zbornik izvlečkov. (pp. 57-58). Ljubljana: ZDSLU.

Zhang, L., \& Sternberg, R. J. (2005). The role of individual differences in approaches to learning. In P. Jarvis \& S. Parker (Eds.), Human learning: An holistic approach (pp. 66-86). London, UK, \& New York, NY: Routledge. 


\section{Biographical note}

EDA BIRSA, PhD, enrolled in doctoral study program Educational Sciences. In 2015 she successfully defended her doctoral thesis "Interdisciplinary Integration in the Classroom of Art Education". Since 2004 she has been employed at the Faculty of Education, University of Primorska, where she works in the field of Art didactics and Art education. 